Normanica Nunc Primum Edita. Pp. 1xiv $+31 \%$.

(Oxonii : E. Typographeo Clarendoniano.) 28s. net.

Rudiments of Electrical Engineering. By P. Kemp.

Pp. viii +255. (London: Macmillan and Co., Ltd.) 6s.

The Ila-Speaking Peoples of Northern Rhodesia.

By the Rev. E. W. Smith and Capt. A. M. Dale.

Vol. i., pp. xxvii+423; vol. ii., pp. xiv +433 .

(London: Macmillan and Co., Ltd.) Two vols., 505. net.

The Early History of Surgery in Great Britain : Its Organisation and Development. By Dr. G. Parker. (Medical History Manuals.) Pp. ix +204 . (London : A. and C. Black, Ltd.) 7s. 6d. net.

Elementary Dynamics: A Text-book for Engineers. By J. W. Landon. Pp. viii +246 . (Cambridge : At the University Press.) Ios. 6d. net.

Memoirs of the Geological Survey. Summary of Progress of the Geological Survey of Great Britain and the Museum of Practical Geology for I919. Pp. 7o. (London: E. Stanford, Ltd.) 2s. 6d. net.

Companions: Feathered, Furred, and Scaled. By

C. H. Donald. Pp. ix + r59. (London: John Lane;

New York: The John Lane Co.) $7 s$. net.

Essentials of Physiology. By Prof. F. A. Bainbridge and Prof. J. A. Menzies. Fourth edition. Pp. viii +497 . (London: Longmans, Green and Co.) is s. net.

\section{Diary of Societies.}

THURSDAY, OCTOBRR 21

Rotal SOCIETY or JrEDICINE (Dermatology Section), at 5 .

ROYAL ARBONATICAI. SOCIETY (at Royal Society of Arts), at $\mathbf{5 . 3 0}$ Squad-Lidr. R. M. Hill: A Comparigon of the Fiying Qualities Squad.-Ldr. R. M. Hill: A Comparison of the Fiying Qualities
of Bingle- and Twinengined Aeropianes.-C. Baker: Night of ing.

INstimtion of Mrining and Matalicrax (at Geological Society), Special General 3eeting, at $\mathbf{5 . 3 0}$; at 5.45.-J. Morrow Campbell: The Origin of Primaty Ore Depnsits.

Crild-STUd Socirtx (at Royal Samitary Institute), a.t 6.-Dr. A. R Abelson: A Psychological Study of the Delinquent Child. FRIDAY, OCTOBER 22.

Royal Colltak of Surarons or Eneland, at 5.-Prof. A. Keith: Demonstration on the Contents of the Museum.

Rozal Society or MEDicise (Study of Disease in Children sec tion), at 5 .

Ineriturtos or Mechanicar Exginkres, at 6.-Capt. H. Riall Sankey: Presidential Address.

Royal. Photographic Society of Great Britans, at 7.-bi. MrartinDuncan: Birds and Beasts from many Lands.

JTNIOR INATITITIOY of ENGINEERs (at Caston Hall), at 8-A. H. Fitt: Impulse Turbines.

RoYA. SOCIETT OF Tropicat MFDICIN (at 11 Chandos Street. W.1) at 8.30.-Prof. W: Yorke: The Present Posttion of Trypanosomiasis Research.

\section{MONDAY, OCTOBER 25}

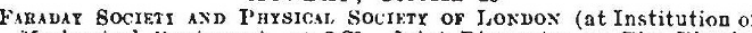
Ifechanical kingineers), at 2.30.-Joint Discussion on The Phrsic and Chemistry of Colloids and their Bearing on Industrial Questions. Prof. The Svedberg: A Short Survey of the Physics and Chemistry of Colloids.-Discussion on Emulsions nod Emulsifen tion. Opener: Prof. F. G. ILonnan.-W. Clayton: Emulsion Probiems in Margarine Manufacture.-S S. Bhatuagar: Reversal of Phuses in Finulsions and precipitation of Suspensoids by Electrolysis: nn Anulogy -Discussion on Physicnl Properties Elcertie (t) Epeners: E Hutschek and Prof. H. R. Procter -S. C. Bradford: The Reversible Sol-gel I'ransformationDr. J. O. W. Barratt: The Structure of Gels.-Discussion on thess and Pyrosols. Opener: Sir Herbert Jackson. Discussion Robert Rohertson, F S Sproston. Nitrocelnhlose Opener: Sir Kobert Rnhertson.-F. Sproxton: Non-Aquenous Colloid Srstem with Special Reference to $\mathrm{Nitrocellulose}-1) \mathrm{Dr}$. G Barr and I.. I. Bircumshan : The Visensity of Some Cellulose $A$ cetat
Solutions. (b) Rubber. Orener: B. D. Porritt: The Action of I.ight on Rubber. - Discussion on Precipitation in Dispers Systems. Onenrers: Dr. R. C. Tolman and Dr. R. S. Willows. J $X$ Mukheriec: The Origin of the Charge of a Colloidal Particle and its Neutralisation hy Flectrolytes- $-\pi$. Clayton: Comgulation of Inorganic Suspensions by Emulsions.-Discussion on Catanhoresis and Flectroendosmose. Opener: Prof A. Ir. Porter--Dr. W. Ormandv: Some Practical Applications of Flectro-endosmose and Cataphoresis.

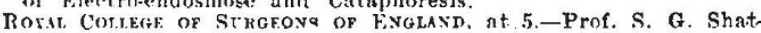
tock: Demonstration of Prthological Specimens in the Yrusmum ROFAL SOCIFT of MEDTCINR (Odontology Section). at 8.-W! $\mathrm{H}$.

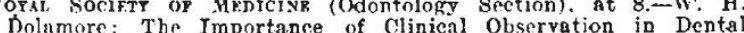
Silrerer (Prosidentini Address).

MFnICA, Soctetr of Lospos, at 830 --Prof. T. B. Leathes and No. 2660 , voL. I 06$]$ others: Discussion on The Determination of Degreo of Renal Function.

\section{TUESDAY, OCTOBER 26}

Sociological, Socretx (at 65 Belgrave Road), at 5.15.-H. Carter and $R$. Unwin: Impressions of the New Germany.

RoYaL SocietX or MEDICINE (Medicine Section), at $5.30-\mathrm{Dr}$. F. Parkes Weber: The Differentistion of the Secbndary Form $\theta$ of Polycythæmia Rubra.-Dr. Paterson: Notes on a Case of Transient Yolycythemia in a Child.

Rorat A Trmopoloo ICAL INETITUTe, at 815-Rey. R. A. Lorrain The Wild Head-hunting Tribes of Lakherland: their 3anners and Customs.

WEDNESDAY, OCTODFR 27.

InstittTe of Afronatical Engikeghe (at Royal College of Science), at $7.45 . \rightarrow$ Col. N. T. Belaiew: The Structure of Steel.

THURSDAY, OCTOBER 28.

Chralacal Societr (at Institution of Meohanioal Engineers), at 8. 1)r. M. O. Forster: The Emil Fischer Memorial Lecture

ABErXetriay Socisty (at St. Bartholomew's Hospital), at 8.30.Sir St. Clair Thomson: Recolleotions of Joseph Lister by one of his Hopse-ourgeone

of his Oral sociar or Horder: The Treatment of sur an decount of bour Cases.- Ti Bonnes: A New Opera tion; for Nephroptosis.

FRIDAY, OCTOBRR 29.

Royal Grogmphical Societr (at the Dolian Hall), at 5. T. A Barns: In the Land of tho Okapi and the Gorilla.

ROTAL COLLEG OF SUBgeons of ENGLAND, at 5.-Prof. A. Keith Demonstration on the Contents of the Museum.

INSTITUTION or MrCBanical ENoINEers (Informal Meeting), at 7 . Rotal Photographic Society of Great Britain. at $t$. Bennett: Winchester: The Cathedral, the School, and the Hos pital of 8t. Cross.

Chrm

Mleeting.
Rorar. Societr of MrDicins (Epidemiolagy and State Mredicise

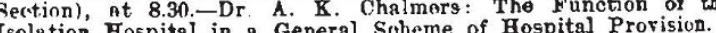

CONTENTS.

PAGE

Methods and Aims of Anthropology . . . . . 233 The Durability of Maritime Structures. By Dr. Brysson Cunningham

Tropical Disease and Administration. By W. G. K. 236 Yearbooks of Universities . . . . . 237 Encyclopadic Chemistry. By J. R. P. . . . . 2 238 Our Bookshelf

Letters to the Editor:-

"Momiai."-Lt.-Col. H. H. Godwin-Austen,

F.R.S. "Thermodynamics."-Sir J. A. E Ewing, K.C.B., F.R.S

A Diver's Notes on Submarine Phenomena - Lieut. Comdr. G. C. C. Damant . . . . . . . 242

Old Irish Maps,-T. Sheppard .. . . . . 243

A Visual Illusion.-Dr. C. S. Myers, F.R.S. ; Dr. A. Wohlgemuth; Capt. C. J. P. Cave . Dy

Possible New Sources of Power Alcohol. By C. Simmonds History of Everyday Creatures. The Natural History of Everyday Creatures. Obituary :-

Prof. Yves Delage. By Prof. J. Arthur Thomson D. . . 248

...... 249

Our Astronomical Column :-

The Nova in Cygnus . . . . . . . . 254

Connection of Planetary Nebula with Helium Stars. 254

Our Conceptions of the Processes of Heredity. II. (With Diagrall.) By Miss E. R. Saunders, F.L.S. 25 The Air Conference, Ig20. By R. T. G.

Annual Report of the Meteorological Committee. By E. M. W.

Proposed British Institute for Geodetic Training and Research. By Dr. E. H. Griffiths, F.R.S., and Major E. O. Henrici

The Imperial College as a University of Science and Technology

Agriculture in Egypt and Cyprus . . . . . .

Heredity and Eugenics . . . . . . . . . 264

University and Eهucational Intelligence $\because 26$

Socioties and Academies........ . . . . 266

Books Received . . . . . . 267

Diary of Societies . . . . . . . . . . . 26 